\title{
AGRICULTURAL PRICES OF PORK AT THE REGIONAL LEVEL AND THE LAW OF ONE PRICE
}

\author{
Petra Bubáková*
}

\section{The law of one price and the research question}

Farmers' main income is earned from selling agricultural commodities, which is their primary activity. Subsidies are helpful for rural areas, but they are not a source of income stability. Stability as well as the level of income are determined by the amount of production and market prices. It is important to be concerned about the issue of price transmission, and try to verify whether general economic theory is also valid in the agricultural sector. Tvrdoň (1992) stated that the agro-food market, as a tool of effective allocation, is not as efficient as other markets for non-agricultural products. Prices and price policies in the agricultural market could have a big impact on the success of programmes themselves. Chen Xiaohua (2009), in his paper about achievements and challenges in rural development in China, mentioned that constraints on increasing agricultural prices are one of the reasons why it is difficult to sustain increases in farmers' incomes.

Considerable changes in the level of market prices have been evident in the Czech Republic in recent years. There was a significant price growth in the period from 2007 to 2008. One of the factors was the growth in demand for basic foodstuffs, especially in economically developing countries like China, Brazil and India. The second reason for this growth in demand was the higher level of processing costs and higher prices for input products such as manure, diesel oil, etc., which increased due to the high cost of energy. Another reason was bad weather, which lead to poor crops from major producers (European Commission, 2009). After the price increases, the situation of some products (for example, milk, wheat and eggs) turned around in the middle of 2008 and prices started to fall. In some cases, they even fell below the price level at the beginning of 2007. These changes have an effect on the agriculturists' income. This tendency has been recognized in recent years, but we can focus on a spatial perspective of price changes as well. We can investigate the price transmission between individual regions of the Czech Republic on the same vertical chain. Vavra and Goodwin (2005) pointed out that, from an economic point of view, the "Law of One Price" should be valid. The definition of this law is as follows: "An economic law which states that in an efficient market all identical goods must have only one price. Thus, in the absence of transportation and other transaction costs, competitive markets will equalize the

\footnotetext{
* Czech University of Life Sciences Prague, Faculty of Economics and Management (bubakova@pef.czu.cz).
} 
price of an identical good in two countries when the prices are expressed in the same currency." (Vavra, Goodwin, 2005, p. 27) The Law of One Price is defined for the world market; however, it is also possible to apply this idea at disaggregated levels. For example, we can study this issue at the regional level of one country. It is possible to find price differences between regions, but this should be possible only in the short term. On the contrary, prices should be identical over the long term. If the Law of One Price is valid, the elasticity of price transmission is equal to one. This paper focuses on research of relationships between prices at the regional level. The investigated regions are North Bohemia and Central Bohemia. Data for Moravia are not provided. South Bohemia is not included in this analysis, because results which represent these regions are problematic and ambiguous.

The selected regions contain urban, rural and mixed areas according to the new typology of NUTS 3. There should be differences between urban and rural areas which are reflected in prices of commodities. The Law of One Price should not be valid if these differences exist. The research question is whether it is correct to regard areas in the Czech Republic as rural areas, while the distances between urban and rural areas are short; therefore, there is good transport between regions. The Law of One Price could be valid in this case.

The aim of this paper is to evaluate the relationship between prices at the regional level in selected regions of Bohemia and try to confirm that the Law of One Price is valid there. This should allow us to obtain information about market behaviour and contribute to decision-making about applications for rural development.

\section{Materials and methods}

Agricultural prices of the pork producers SEU were chosen for the analysis. Since it is necessary to have a sufficiently large number of observations, observations from the $13^{\text {th }}$ and $27^{\text {th }}$ day of each month are used in this paper. This represents an approximately two-week data period frequency. The first observation is from $27^{\text {th }}$ June 2002 and the last observation is from $27^{\text {th }}$ December 2008. The data set has 157 observations in total. No other data have been published since 2009. The data set was obtained from Market Reports - Beef and Pork, which are provided by the State Agricultural Intervention Fund. These published data are based on agricultural pork prices in $\mathrm{CZK} / \mathrm{kg}$ in the selected cluster of regions. For the analysis, the following regions were selected: Central Bohemian (CB), which consists of the regions of Prague and Central Bohemia, North-Eastern (N_E), which consists of the regions of Liberec, Hradec Králové and Pardubice, and finally North-Western (N_W), with the regions Ústí nad Labem and Karlovy Vary. Consequently, 7 out of 14 regions of the Czech Republic are analyzed in this paper. Agricultural prices of pork in Czech crowns per kilogram are shown in Figure 1. 


\section{Figure 1}

\section{Agricultural prices of pork in Czech crowns per kilogram} from 2002-06-27 to 2008-12-27
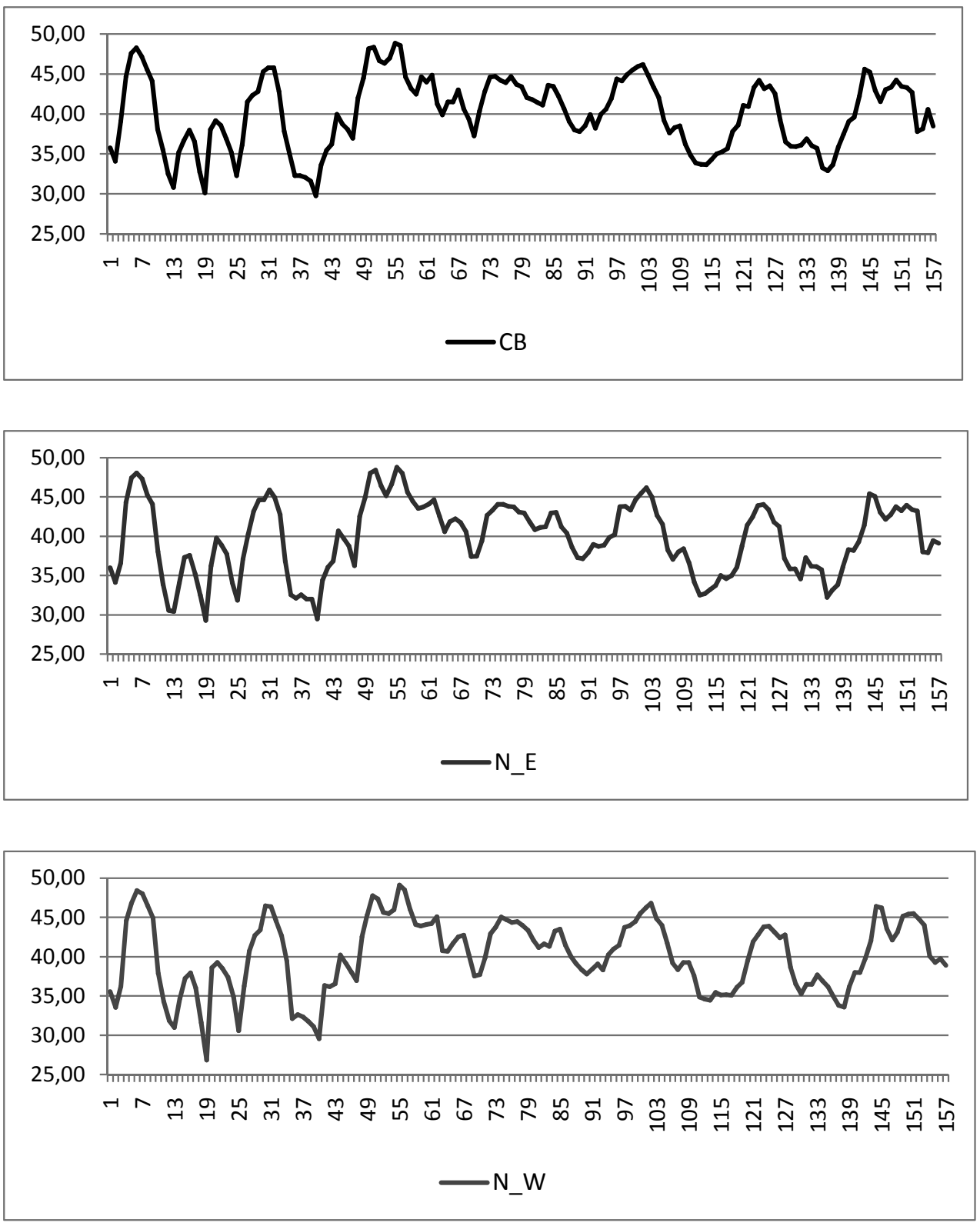

Source: State Agricultural Intervention Fund 
For investigating the relationships between the prices and the Law of One Price, validation research econometric methods were used, namely the Vector Error Correction Model (VECM) (Arlt, 2007; Charemza and Deadman, 1997).

A logarithmic transformation of the time series was chosen for the purposes of this article. Accordingly, variables are in a hyperbolic logarithm of the original time series. The order integration, I(d), is determined using the Augmented Dickey-Fuller (ADF) test (1979). The ADF test is the most common test in empirical analyses and is applied in evaluation of the stationarity of time series. Delayed variables of the endogenous variable are included in the test model for resolving problems with the possibility of autocorrelation of a random variable. The optimal lag is determined on the basis of an automatic selection of Schwartz Info Criterion (SIC), where maximum lags are twentyfour. The Kwiatkowski-Phillips-Schmidt-Shin (KPSS) test (1992) is used for verification of the results of the previous test. The KPSS test is another way of evaluating the stationarity of time series. The spectral estimation method of the KPSS test is based on AR spectral - OLS (EViews 4 User's Guide, 2002).

The cointegration between time series is verified with the use of the Johansen cointegration test. Firstly, the optimal lag of the VAR model is determined on the basis of information criteria, namely the Akaike information criterion (AIC), Schwarz information criterion (SIC) and Hannan and Quinn information criterion (HQ) (Green, 2007; Hušek, 2007). The VAR model is estimated and the cointegration test is computed. Finally, the Vector Error Correction Model is estimated.

For the analysis and estimates, EViews, version 4, was used.

\section{Vector error correction model creation and its results}

\subsection{Test of stationarity}

We can consider stationarity of the time series according to Figure 1, but it is necessary to confirm this assumption. Because the prices of pork fluctuate around a constant, we use the ADF test without a constant, in other words, without a drift. The results of the test are shown in Table 1. Under the null hypothesis of the ADF test, the time series is nonstationary. The p-values of the ADF test are at a high level, so we cannot reject the null hypothesis. The time series are nonstationary in the original logarithmic data. Testing the first differences shows stationarity of the time series. According to this test, the order of integration of these prices is equal to one, i.e. I(1). This is a different result than what we had expected. It should be noted that if we try to use the ADF test with a constant, unfortunately the time series are stationary, $\mathrm{I}(0)$.

The results of the KPSS test support the first results of the ADF test without a constant. The results are shown in Table 1. The difference from the ADF test is that under the null hypothesis, the time series has stationarity. The t-statistics of the KPSS test are higher than the critical values; therefore, we reject the null hypothesis about stationarity. Time series are stationary in the first differences. Two out of the three tests attest to the first order of integration of the time series. We can continue the process of 
VECM model development. If the time series are indeed stationary, this turns up in the Johansen cointegration test.

Table 1

Results of ADF and KPSS unit root tests

\begin{tabular}{|c|c|c|c|c|c|c|c|}
\hline \multirow{2}{*}{\multicolumn{2}{|c|}{\begin{tabular}{|l|} 
ADF test \\
without constant
\end{tabular}}} & \multicolumn{3}{|c|}{ Original logarithmic data } & \multicolumn{3}{|c|}{ First differences } \\
\hline & & CB & N_E & N_W & CB & N_E & N_W \\
\hline \multicolumn{2}{|c|}{ t-statistic } & 0.00275 & 0.01036 & 0.02075 & -9.13374 & -8.81491 & -10.2443 \\
\hline \multicolumn{2}{|l|}{$p$-value } & 0.6803 & 0.6845 & 0.6879 & 0.0000 & 0.0000 & 0.0000 \\
\hline \multicolumn{2}{|c|}{ KPSS test } & $\mathrm{CB}$ & N_E & N_W & $\mathrm{CB}$ & N_E & N_W \\
\hline \multicolumn{2}{|c|}{ t-statistic } & 1.05721 & 0.88746 & 1.21808 & 0.04158 & 0.03534 & 0.02996 \\
\hline \multirow{3}{*}{$\begin{array}{l}\text { Critical } \\
\text { values }\end{array}$} & $1 \%$ level & 0.739 & 0.739 & 0.739 & 0.739 & 0.739 & 0.739 \\
\hline & $5 \%$ level & 0.463 & 0.463 & 0.463 & 0.463 & 0.463 & 0.463 \\
\hline & $10 \%$ level & 0.347 & 0.347 & 0.347 & 0.347 & 0.347 & 0.347 \\
\hline
\end{tabular}

\subsection{Cointegration test}

Before using a cointegration test, it is necessary to create an appropriate VAR model. On the basis of the AIC, SIC and HQ criteria, the optimal number of lags was set to two. The results of the VAR lag order selection are shown in Table 2.

\section{Table 2}

Results of VAR lag order selection criteria

\begin{tabular}{|l|c|c|c|}
\hline Lag & AIC & SIC & HQ \\
\hline $\mathbf{0}$ & -11.39750 & -11.33701 & -11.37292 \\
\hline $\mathbf{1}$ & -12.93388 & -12.69195 & -12.83559 \\
\hline $\mathbf{2}$ & $-13.14557^{*}$ & $-12.72219^{*}$ & $-12.97356^{*}$ \\
\hline $\mathbf{3}$ & -13.06766 & -12.46284 & -12.82193 \\
\hline $\mathbf{4}$ & -13.02928 & -12.24301 & -12.70983 \\
\hline $\mathbf{5}$ & -12.99909 & -12.03138 & -12.60592 \\
\hline $\mathbf{6}$ & -13.02115 & -11.87199 & -12.55427 \\
\hline $\mathbf{7}$ & -13.05277 & -11.72216 & -12.51216 \\
\hline $\mathbf{8}$ & -13.02530 & -11.51325 & -12.41098 \\
\hline
\end{tabular}

* indicates lag order selected by the criterion

AIC: Akaike information criterion

SIC: Schwarz information criterion

$H Q$ : Hannan-Quinn information criterion 
A VAR model with two delays of endogenous variables was created, and the ensuing cointegration test was used. The results of the summary test of Johansen cointegration are shown in Table 3. In this summary test, different types of VECM are considered, and the numbers of Trace and Max-Eig determine the numbers of cointegration relationships (number of cointegrating equations).

\section{Table 3}

\section{Johansen cointegration test summary}

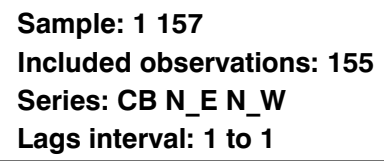

\begin{tabular}{|l|c|c|c|c|c|}
\hline $\begin{array}{l}\text { Data } \\
\text { Trend: }\end{array}$ & None & None & Linear & Linear & Quadratic \\
\hline $\begin{array}{l}\text { Rank or } \\
\text { no. of CEs }\end{array}$ & No Intercept & Intercept & Intercept & Intercept & Intercept \\
\cline { 2 - 6 } & No Trend & No Trend & No Trend & Trend & Trend \\
\hline Selected (5\% level) Number of Cointegrating Relations by Model (columns) & 3 & 3 \\
\hline $\begin{array}{l}\text { Trace } \\
\text { Max-Eig }\end{array}$ & 2 & 3 & 3 & 3 & 3 \\
\hline
\end{tabular}

Only when the rank of the matrix $\Pi$ is lower than the full rank and greater than zero are the time series cointegrated, and it is then possible and necessary to use the VECM model. In Table 3, we can see that a cointegration relationship exists only in the case of a model with no intercept and no trend. The number of cointegration equations is two. Other possibilities have three relationships, which is a full rank matrix $\Pi$, which indicates a stationary process. Table 3 is not the main result of the Johansen test but confirms the results of the ADF tests, where the model without a constant shows nonstationarity and the model with a constant shows stationarity. There are long-run relationships between the time series, but we have to use a model without a constant and a trend. The main result of the Johansen test for the discussed model is shown in Table 4. There are two cointegrated relations according to the Trace statistic. 


\section{Table 4}

Johansen cointegration test, no intercept, no trend

\begin{tabular}{|c|c|c|c|c|}
\hline \multicolumn{5}{|c|}{$\begin{array}{l}\text { Sample (adjusted): } 3157 \\
\text { Included observations: } 155 \text { after adjusting endpoints } \\
\text { Trend assumption: No deterministic trend } \\
\text { Series: CB N_E N_W } \\
\text { Lags interval (in first differences): } 1 \text { to } 1\end{array}$} \\
\hline \multicolumn{5}{|c|}{ Unrestricted Cointegration Rank Test } \\
\hline $\begin{array}{l}\text { Hypothesized } \\
\text { no. of CEs }\end{array}$ & Eigenvalue & $\begin{array}{c}\text { Trace } \\
\text { Statistic }\end{array}$ & $\begin{array}{l}5 \text { Percent } \\
\text { Critical Value }\end{array}$ & $\begin{array}{c}1 \text { Percent } \\
\text { Critical Value }\end{array}$ \\
\hline None ** & 0.300039 & 98.36809 & 24.31 & 29.75 \\
\hline At most 1 ** & 0.242628 & 43.07484 & 12.53 & 16.31 \\
\hline At most 2 & 1.77E-06 & 0.000274 & 3.84 & 6.51 \\
\hline
\end{tabular}

${ }^{*}(*)$ denotes rejection of the hypothesis at the $5 \%(1 \%)$ level

Trace test indicates 2 cointegrating equations at both $5 \%$ and $1 \%$ levels

\subsection{Vector Error Correction Model}

On the basis of the previous results, a Vector Error Correction Model with two cointegrating equations was created. The first result of this model is shown in Table 5. It contains only the results of long-run relationships and the results of the estimated coefficients $\beta$ and $\alpha$. The vector $\beta$ represents a cointegrating vector and $\alpha$ represents a loading parameter. Vectors $\beta$ are part of cointegrating equations, and the output error correction is represented by vectors $\alpha$, which are multiplied by vectors $\beta$. The statistical significance coefficients are denoted in bold. The numbers in square brackets are t-statistics of coefficients. 


\section{Table 5}

Results of VECM estimates, long-run relationship

\begin{tabular}{|c|c|c|c|}
\hline \multicolumn{4}{|c|}{$\begin{array}{l}\text { Vector Error Correction Estimates } \\
\text { Sample (adjusted): } 3157 \\
\text { Included observations: } 155 \text { after adjusting endpoints } \\
\text { Standard errors in () \& t-statistics in [ ] }\end{array}$} \\
\hline \multicolumn{4}{|c|}{$\begin{array}{l}\text { Convergence achieved after } 1 \text { iteration. } \\
\text { Not all cointegrating vectors are identified. } \\
\text { Restrictions are not binding (LR test not available). }\end{array}$} \\
\hline Cointegrating Eq: & CointEq1 & CointEq2 & \\
\hline $\mathrm{CB}(-1)$ & 1.000000 & -0.501443 & \\
\hline N_W(-1) & -0.501054 & 1.000000 & \\
\hline N_E(-1) & -0.499610 & -0.500387 & \\
\hline Error Correction: & $\mathrm{D}(\mathrm{CB})$ & $D\left(N \_W\right)$ & $\mathrm{D}\left(\mathrm{N}_{-} \mathrm{E}\right)$ \\
\hline \multirow[t]{3}{*}{ CointEq1 } & -0.245942 & 0.237236 & 0.767877 \\
\hline & $(0.35036)$ & $(0.39046)$ & $(0.35859)$ \\
\hline & {$[-0.70198]$} & {$[0.60758]$} & [ 2.14138] \\
\hline \multirow[t]{3}{*}{ CointEq2 } & -0.901450 & -1.299076 & -0.264669 \\
\hline & $(0.32672)$ & $(0.36413)$ & $(0.33440)$ \\
\hline & [-2.75905] & {$[-3.56766]$} & {$[-0.79147]$} \\
\hline
\end{tabular}

The VECM model cannot be used, because cointegrating vectors are not identified. Therefore it is necessary to specify the identifying restrictions. The coefficient of $\mathrm{D}\left(\mathrm{N}_{-} \mathrm{E}\right)$ in the first cointegrating equation is only one, which is statistically significant. We can assume that there is no relationship between prices in CB and prices in N_W (insignificant coefficient); therefore, the first restriction that equals zero will be at the parameter $b$ for $N_{-} W(-1)$ in the first cointegrating equation. Two coefficients $(\mathrm{D}(\mathrm{CB})$; $\left.\mathrm{D}\left(\mathrm{N} \_\mathrm{W}\right)\right)$ are statistically significant in the second cointegration vector. It is probable that N_E$_{-}(-1)$ has no effect in the second cointegrating vector, and hence this parameter will be restricted to zero. The results of this modified model are shown in Table 6 . There are long-run as well as short-run relationships. Statistical characteristics of the model are shown in Table 7. Other restrictions were estimated, but the model in Table 6 has the best results from a statistical and economic point of view. 


\section{Table 6}

\section{Results of VECM estimates, model with restrictions}

\begin{tabular}{|c|c|c|c|}
\hline \multicolumn{4}{|c|}{$\begin{array}{l}\text { Vector Error Correction Estimates } \\
\text { Sample (adjusted): } 3157 \\
\text { Included observations: } 155 \text { after adjusting endpoints } \\
\text { Standard errors in ( ) \& t-statistics in [ ] }\end{array}$} \\
\hline \multicolumn{4}{|c|}{$\begin{array}{l}\text { Convergence achieved after } 1 \text { iteration. } \\
\text { Restrictions identify all cointegrating vectors. } \\
\text { Restrictions are not binding (LR test not available). }\end{array}$} \\
\hline Cointegrating Eq: & CointEq1 & CointEq2 & \\
\hline \multirow[t]{3}{*}{$\mathrm{CB}(-1)$} & 1.000000 & -1.000776 & \\
\hline & & $(0.00073)$ & \\
\hline & & {$[-1371.19]$} & \\
\hline N_W(-1) & 0.000000 & 1.000000 & \\
\hline \multirow[t]{3}{*}{$N_{-} E(-1)$} & -1.002112 & 0.000000 & \\
\hline & $(0.00057)$ & & \\
\hline & {$[-1755.85]$} & & \\
\hline Error Correction: & $\mathrm{D}(\mathrm{CB})$ & D(N_W) & $\mathrm{D}\left(\mathrm{N}_{-} \mathrm{E}\right)$ \\
\hline \multirow[t]{3}{*}{ CointEq1 } & -0.572740 & -0.530395 & 0.250673 \\
\hline & $(0.30421)$ & $(0.33903)$ & $(0.31136)$ \\
\hline & [-1.88272] & {$[-1.56444]$} & [ 0.80510] \\
\hline \multirow[t]{3}{*}{ CointEq2 } & -0.778220 & -1.417944 & -0.649416 \\
\hline & $(0.25745)$ & $(0.28693)$ & $(0.26350)$ \\
\hline & {$[-3.02275]$} & {$[-4.94185]$} & [-2.46453] \\
\hline \multirow[t]{3}{*}{$\mathrm{D}(\mathrm{CB}(-1))$} & -0.185201 & 0.051636 & 0.068052 \\
\hline & $(0.23208)$ & $(0.25864)$ & $(0.23753)$ \\
\hline & {$[-0.79801]$} & [ 0.19964] & [ 0.28650] \\
\hline \multirow[t]{3}{*}{$\mathrm{D}\left(\mathrm{N} \_\mathrm{W}(-1)\right)$} & 0.393270 & 0.235262 & 0.308593 \\
\hline & $(0.20663)$ & $(0.23028)$ & $(0.21148)$ \\
\hline & [ 1.90327] & [ 1.02162] & [ 1.45917] \\
\hline \multirow[t]{3}{*}{$\mathrm{D}\left(\mathrm{N} \_\mathrm{E}(-1)\right)$} & 0.087013 & 0.075252 & 0.039740 \\
\hline & $(0.23833)$ & $(0.26561)$ & $(0.24393)$ \\
\hline & [ 0.36509] & [ 0.28332] & [ 0.16291] \\
\hline
\end{tabular}




\section{Table 7}

Statistical characteristics of the VECM, model with restrictions

\begin{tabular}{|llll|}
\hline R-squared & 0.167687 & 0.251165 & 0.222082 \\
Adj. R-squared & 0.145492 & 0.231196 & 0.201337 \\
Sum sq. resids & 0.395925 & 0.491758 & 0.414753 \\
S.E. equation & 0.051376 & 0.057257 & 0.052583 \\
F-statistic & 7.555162 & 12.57778 & 10.70559 \\
Log likelihood & 242.7362 & 225.9371 & 239.1355 \\
Akaike AIC & -3.067563 & -2.850802 & -3.021104 \\
Schwarz SC & -2.969388 & -2.752627 & -2.922929 \\
Mean dependent & 0.000787 & 0.000955 & 0.000884 \\
S.D. dependent & 0.055578 & 0.065301 & 0.058839 \\
Determinant Residua & & $4.00 \mathrm{E}-10$ & \\
Covariance & & 1024.870 & \\
Log Likelihood & & 1017.247 & \\
Log Likelihood (d.f. adjusted) & -12.85480 & \\
Akaike Information Criteria & -12.44246 & \\
Schwarz Criteria & & &
\end{tabular}

The cointegrating vectors are identified. The values of the t-statistics are higher than in the first case in Table 5. Other restrictions were tried, but no better result was found. This model will be used in the following discussion.

\section{Discussion}

The coefficient of the delayed variable N_E is statistically significant in the first cointegrating equation. If we look at the results of error correction of the first cointegrating equation, only the first coefficient $\mathrm{D}(\mathrm{CB})$ is statistically significant, at a $10 \%$ level of significance. The critical t-value for evaluation is 1.655 to this level of significance. The parameter $\mathrm{D}\left(\mathrm{N} \_\mathrm{E}\right)$ is not statistically significant. From these results, it can be presumed that prices in the North-Eastern regions are exogenous and have an effect on the prices in Central Bohemia, but there is no influence of Central Bohemia on the North-Eastern regions. If the agricultural price of pork in the North-Eastern regions rises by $1 \%$, the price increase in the Central Bohemian regions will be $1.002 \%$. The long-run relationship can be written as:

$$
C B_{t-1}=1.002112 N_{-} E_{t-1}+u_{1 t}
$$

The second cointegrating equation also has a statistically significant coefficient of the variable $\mathrm{CB}(-1)$. The coefficients are all statistically significant at a $5 \%$ level of significance, and for variables $\mathrm{D}(\mathrm{CB})$ and $\mathrm{D}\left(\mathrm{N}_{-} \mathrm{W}\right)$ also at a $1 \%$ level of signifi- 
cance. We can assume that prices in the Central Bohemian regions and in the NorthWestern regions have a mutual influence. In this regression, if the price in Central Bohemia grows by $1 \%$, the price in the North-Western regions increases by $1.0008 \%$. The long-run relationship can be written as follows:

$$
N_{-} W_{t-1}=1.0008 C B_{t-1}+u_{1 t}
$$

The coefficients which indicate changes in a long period are very close to the number 1. This is the Law of One Price which was mentioned at the beginning of this paper. On the basis of these results, it is possible to suppose with a high probability that this law is valid in the investigated regions. The test about the equality of the coefficient to the number one will be confirmed with a high probability, because the difference between the coefficients and the number one is very small, and in addition, there is a small standard error of the estimated coefficients.

It has been confirmed in the above text that the Law of One Price is valid. Now, we can discuss what this information means from the economic point of view. Firstly, the law is valid regardless of whether that region is an urban area or a rural area. In the context of the research question, prices are not influenced by rural areas and their specifications. A strict delimitation of rural and urban areas is not convenient in this case.

Secondly, there can be two very different explanations to the law. The first is that there is a perfect competition in the investigated area because the law is valid. The market operates in order and no state intervention is needed. We should consider that the investigated area (i.e., Central Bohemian, North-Eastern and North-Western regions) is a small area from the distance point of view. The market does not show any great spatial dispersion. Another fact is that the product is not differentiated. These things are typical for perfect competition. In addition, we can mention that in the case of agricultural prices there are a large number of sellers, i.e., farmers. Therefore, they should not be able to agree one price. This is also the case of perfect competition.

But there is another very important actuality. Agricultural prices are not prices at which farmers want to sell, but final prices at which the processors buy pork from farmers. There have been numerous investigations that farmers do not have a strong position on the agricultural market. The number of buyers is smaller; therefore, they can dictate final prices. There are three main concerns which control the majority of retail market, i. e., Tesco Stores ČR, REWE and Schwarz. This number of enterprises on the market is characteristic of oligopolistic and oligopsonic competition. There can be a strong influence from the concerns, i.e., ultimately the retailers. If we consider this fact, there is another result in the interpretation of the Law of One Price concerning the agricultural prices of pork. The second explanation is that there is an imperfect competition on the market and there is an agreement between the concerns which leads to identical prices. This agreement, denoted as a cartel, is illegal and in this situation a state intervention is needed.

From another point of view, it should be noted that the same price in an oligopolistic and oligopsonic structure of the market does not have to be caused only by an illegal agreement. The identical prices may be caused, for example, by a good information situation about concurrent competitors' prices. Identical prices are also typical 
for a Cournot or Bertrand solution on markets with homogenous products, which pork is. Cournot and Bertrand models in game theory look into the size of the final production and the price in non-cooperative enterprise strategies. The models result in a situation where firms sell products (or buy in an oligopsonic structure) for identical prices. All this should be considered carefully when we want to interpret the validity of the Law of One Price on the pork market.

\section{Conclusion}

The aim of this paper was to evaluate the relationship between prices at the regional level for the selected regions and to confirm whether the Law of One Price is valid there. The Johansen test has confirmed the cointegration between the time series and determined two cointegrating equations. On the basis of the Vector Error Correction Model, it was found that prices in the North-Eastern regions have an effect on prices in Central Bohemia. It was also discovered that prices in the Central Bohemian regions and prices in the North-Western regions interact. If the agricultural price of pork in the North-Eastern regions rises by $1 \%$, the price increase in the Central Bohemian regions will be $1.002 \%$. If the price in the Central Bohemian regions grows by $1 \%$, the price in the North-Western regions increases by $1.0008 \%$.

Prices over the long term are identical with a high probability, or in other words, the Law of One Price is valid. There are some important findings from the VECM model and the discussion of the Law of One Price. Firstly, the Law of One Price is valid with a high level of probability. Secondly, there is an influence of the market being small in area and the product homogeneity on the law. Consequently, the prices are identical regardless of whether that region is an urban area or a rural area. Thirdly, although the Law of One Price is valid, we cannot deduce perfect competition with certainty. On the other hand, we cannot deduce any power abuse by an oligopoly group, because identical prices can be the result of a normal situation, not only an illegal agreement.

It is necessary to mention that the coefficients were not statistically tested. This is a project for future work. Additional software is needed for this purpose. More ideas for further research are to try to investigate the price relation with the EU and try to examine the validity of the law on the bigger market, and try to investigate other agricultural commodities, for example milk, because there are transport limitations.

\section{References}

ARLT, J.; ARLTOVÁ, M. Ekonomické časové řady: vlastnosti, metody modelování, př́íklady a aplikace. 1. vyd. Praha: Grada, 2007. 285 s.

European Commission. Časté otázky týkající se společné zemědělské politiky (SZP) a evropského zemědělství - Ceny potravin [on-line]. Page updated 2009-06-15. [cit. 2011-06-18]. http://ec.europa. eu/agriculture/faq/prices/index_cs.htm.

CHAREMZA W. W.; DEADMAN D. F. New Directions in Econometric Practice: General to Specific Modelling, Cointegration, and Vector Autoregression. 2nd edition. Lyme : Edward Elgar, 1997. 344 p. ISBN 1-85898-603-6.

DICKEY, D.; FULLER, W. Distribution of the Estimators for Autoregressive Time Series With a Unit Root. Journal of the American Statistical Association. Part 1, 1979, vol. 74, Issue 366, s. 427-431. 
GREEN, W. H. Econometric analysis. 6th edition. Chapter 22: Nonstationary Data. New Jersey : Prentice Hall, 2007.

HILL, R. C.; GRIFFITHS, W. E.; GUAY, C. L. Principles of econometrics. 3rd edition. Hoboken, NJ : John Wiley \& Sons, 2008. $597 \mathrm{~s}$.

HUŠEK, R. Ekonometrická analýza. Praha : VŠE, Nakladatelství Oeconomica, 2007. 367 s.

KWIATKOWSKI, D.; PHILLIPS, P. C. B.; SCHMIDT, P.; SHIN, Y. Testing the null hypothesis of stationarity against the alternative of a unit root: How sure are we that economic time series have a unit root. Journal of Econometrics. 1992, vol. 54, Issues 1-3, s. 159-178.

Quantitative Micro Sofware. EViews 4 User's Guide. USA: Quantitative Micro Software, 2002. s. 722.

TVRDOŇ, J. Některé souvislosti teorie a praxe utváření tržní rovnováhy zemědělských a potravinářských výrobků. Collection of works 35/92. Praha : PEF VŠz, 1992.

VAVRA, P.; GOODWIN, B. K. Analysis of Price Transmission along the Food Chain. OECD France [Agriculture and Fisheries Working Papers, No. 3]. OECD Publishing, 2005. www.oecd.org/dataoecd/36/55/40459642.pdf.

XIAOHUA, Chen. Agricultural and Rural Development in China: Achievements and Challenges: Guest Editorial. EuroChoices. 2009, vol. 8, Issue 2, s. 6-9.

\title{
AGRICULTURAL PRICES OF PORK AT THE REGIONAL LEVEL AND THE LAW OF ONE PRICE
}

\begin{abstract}
Farmers earn their main income from selling agricultural commodities. Stability as well as the level of income are determined by the amount of production and market prices. Prices and price policies on the agricultural market could have a great impact on the success of programmes themselves. This paper focuses on research of relationships between prices at the regional level. The aim of this paper is to evaluate the relationship between prices at the regional level for selected regions of Bohemia and try to confirm that the Law of One Price is valid there. Agricultural prices for pork producers were used for the analysis. The data set has 157 observations in total. The first observation is from $27^{\text {th }}$ June 2002 and the last observation is from $27^{\text {th }}$ December 2008. No data have been published by the State Agricultural Intervention Fund since 2009. The investigated groups of regions are the Central Bohemian (CB), North-Eastern (N_E) and North-Western (N_W) regions of the Czech Republic. Econometric methods are used, and the primary tools for research are the ADF test, KPSS test, Johansen cointegration test and Vector Error Correction Model (VECM). On the basis of the VECM model, it was found that prices in the NorthEastern regions have an effect on prices in Central Bohemia. It was also discovered that prices in the Central Bohemian and North-Western regions have a mutual effect. The Law of One Price is valid with a high probability in the investigated regions. Prices in the long run are identical with a high probability. The results were elaborated as part of the research project MSM 6046070906 "Economics of resources of Czech agriculture and their efficient use in frame of multifunctional agri-food systems".
\end{abstract}

Keywords: Agricultural prices, pork, region, Law of One Price, cointegration, Vector Error Correction Model

JEL Classification: C10, D40, Q10 